Article

\title{
Student Concepts after a Didactic Experiment in Heritage Education
}

\author{
Mónica Trabajo-Rite * and Jose María Cuenca-López『 \\ Departament Integrated Teaching, University of Huelva, 21007 Huelva, Spain; jcuenca@uhu.es \\ * Correspondence: monica.trabajo@ddcc.uhu.es
}

Received: 9 March 2020; Accepted: 8 April 2020; Published: 10 April 2020

\begin{abstract}
This work highlights the importance of heritage education as a vehicle for citizen education. We present an analysis of concepts of heritage, citizenship, and territory held by third-year social science students. The results are obtained from statistical analysis of a questionnaire given before and after a didactic intervention and the application of a table of categories drawn up based on heritage education in terms of the parameters we consider desirable, from a holistic, socio-critical, motivating, and participatory perspective. The outcomes show the success of the intervention, with the students presenting better reflective and critical knowledge of their environment, showing appreciation, respect, protection, and dissemination of heritage as a symbol of identity and favoring the commitment to sustainable actions.
\end{abstract}

Keywords: heritage education; citizenship; territorial intelligence; compulsory secondary education

\section{Introduction}

The study and interpretation of heritage provides knowledge of the changes that have taken place over time, revealing the causes and consequences of social, cultural, and environmental changes, understanding heritage as educational content from a holistic, integrational, and complex standpoint. Heritage education is proposed as a training vehicle for citizens to equip them with skills to participate in the social life of their community in a critical and reflective way [1,2].

In formal education, heritage education is closely linked with social science teaching. Numerous studies highlight the need to involve students with their environment, with their knowledge, valuation, enjoyment, use, and dissemination of their heritage as an element that symbolizes the social and cultural identity of communities [3-7].

As part of the HETEIC R+D+i project, "Heritage Education for the Territorial and Emotional Intelligence of Citizens", investigations are underway to detect good practices in heritage education. The research places emphasis on detecting good practices carried out by museums and educational institutions, selecting those more enriching proposals that lay the foundations to carry out didactic experiments that link both institutions. Heritage education is at the core of these experiments, which in turn favor the development of territorial intelligence in the pupils on their way to becoming global, critical, reflexive, committed, and participatory citizens. Territorial intelligence allows us to address the ability to understand the development of territories from a critical and reflective perspective through a multidisciplinary, participatory, and community approach $[8,9]$. Thus, the introduction of heritage as educational content enables us to work with the students on issues related to territory and how it is affected by human presence, as well as the social, cultural, and environmental consequences. The study and interpretation of heritage evinces the changes and evolution of the territory's geographic structure and encourages reflection on the consequences of development from multiple perspectives (economic, social, environmental, cultural, etc.) [8-10]. 
In this sense, we present an analysis of students' conceptions after experimenting with an innovative proposal that places emphasis on the link between school and museum. There are numerous articles on analysis of the conceptions of patrimony and heritage education held by primary and secondary school teachers [4-11]. In our case, we consider that one way to measure the success rate of a didactic intervention is by analyzing the concepts of the students taking part before and after the process.

To this end, the didactic proposal of the study is designed and experimented with the aim of creating an intervention model for heritage education for citizenship training. This proposal links heritage with the parameters of territorial intelligence (sustainability and development of the territory) in a way that addresses development based not only on economic criteria, but also cultural, social and environmental factors. With the implementation of this unit, the aim is to encourage students in the third year of secondary education to reflect on the development of territories in terms of the changes that have occurred and are taking place in them. This need to create awareness of change in students leads us to work on the evolution of economic sectors, focusing on the service sector as a means to demonstrate and understand the impact of change in the territory. To this end, an experiment is carried out with 13 sessions in which they develop various activities related to the tertiary sector and a field trip to the El Pintado Tidal Mill Eco-Museum.

In this study, heritage is conceived as a vehicle whereby students become territorially intelligent citizens. People with capacity to act upon their territory, who know how the development criteria have evolved from being governed solely by economic issues to the emergence of a critical awareness towards the depletion of fossil fuels, waste of materials and energy, the climate impact of production methods, and consumption [9]. This gives rise to great unsustainability, which calls the current development model into question. There is a consensus regarding the unsustainability of the current regime and the priority of promoting a multi-scale socio-ecological transition towards a system with a more respectful relationship with the natural environment. To this end, it becomes necessary to undertake actions focused on transforming infrastructures, demographic patterns, and the current production and consumption model [12].

The citizenry is conceived in this regard as the focus responsible for territorial development, as it is the citizens who act upon the territory, intervening in its evolution, its use, and function. A global citizenry must collaborate in the transformation of territorial structures, attending to the changes that may occur in them [13]. In this line, territorial intelligence is addressed, which means understanding the factors that intervene in the development and sustainability of territories from a critical and reflective perspective, decoupling them from exclusively economic criteria to make way for a multidisciplinary, participatory, and community approach [9]. From this standpoint, heritage is approached as a symbol of sociocultural identity, so that its study and interpretation can favor evidence of change in the geographical structure of the territory and encourage reflection on its consequences from social, cultural, environmental, geographic, and economic perspectives [14]. To this end, it is essential to recover local identities that foster citizenship with individual and collective, national and global identity [15], the awareness of the change regarding development criteria and with the necessary skills to undertake actions designed to transform infrastructures, demographic patterns, and the current model of production and consumption towards models that are more respectful of the natural [12] and cultural environment, in accordance with the premises put forward at the Faro Convention of 2005 (https://www.coe.int/en/web/conventions/full-list/-/conventions/rms/0900001680083746).

From this perspective, it is important to be aware of the consequences and the social and political responsibility involved when working in citizenship training, as the actions in this area are never neutral. So, it is essential to make the meaning of educational research and the implementation of proposals to develop critical, constructive, and participatory skills in students explicit at all times [16]. The aim pursued is the training of critical and participatory citizens based on heritage education, so that they know how economic activities are carried out, by observing their evolution and analyzing their social, cultural, and environmental impact. Developing meaningful learning around the understanding of territorial change is vital for the knowledge of economic development. Understanding economic 
education is not simply about being experts in finance, but providing tools to understand social reality and how society is organized [17] (p. 40). This knowledge gives rise to attitudes of commitment to territorial development and empathy towards other forms of life, valuing the importance of interpersonal relationships in the construction of a common development project. The aim is that pupils should be able to interpret historical, political, social, and cultural events on the basis of studying and interpreting heritage from a systemic, integrating, and complex perspective, working on several heritage typologies (artistic, archaeological, scientific-technological, historical) in an integrated and holistic way. In this way, we transform heritage into a socially dynamizing element that is articulated as a nucleus around which to address social issues close to students. Relevant problems that motivate and mobilize attitudes of commitment to social, territorial, and environmental change. These themes include issues of cultural identity in a globalized world, economic inequalities (through the study of different societies and the types and evolution of trade), environmental conflicts, territorial management and development, urbanism, and sustainable development, by tackling relevant and controversial social problems $[18,19]$.

To develop the current proposal, we set out from the necessary involvement of a museum, which was selected following a series of parameters related to good educational practices (as detailed below). The museum is conceived as a meeting place for citizens; a space for open and flexible communication and dialogue that favors interaction between students and heritage [20]. In this way, the museum that is selected is conceived as a social space, a reflection of citizen identities, offering experiential activities and promoting knowledge of the context, as well as its evolution [21-23].

Student conceptions of heritage tend to reveal a simplistic and limited notion of patrimony, without granting it any social value. Far from considering heritage from a symbolic-identity perspective, the vision that most characterizes students in compulsory education is the monumentalist or artistic, where the oldest element or most majestic and recognized worldwide takes on greater value, as also illustrated in the most common school textbooks [24].

To analyze the evolution of the students' concepts, we created a progression hypothesis that sets out three levels [25], following the works of Cuenca [26] (Figure 1).

\section{Research Design}

The aim of this research is to provide a heritage education-based didactic model that promotes the link between the school and the museum as a determining factor in the formation of critical, responsible, reflective, and participatory citizens $[13,27]$. We set out from a basic problem for the research.

To what extent do the conceptions of students in secondary education change after the experience of a didactic proposal for heritage education linking school and museum, working on the premises of territory, identity, and citizenship?

In this sense, the main objective is to demonstrate the impact of the implementation of innovative teaching proposals on students' conceptions and, therefore, on their learning in the scope of heritage education. We understand that innovative proposals are interactive and work by applying an active methodology that allows teacher and student interaction, while affording students an active role. In these proposals, critical contents are developed through direct contact of the students with the environment, and learning about and working on the territory.

\subsection{Informants}

We analyzed the concepts of the case-group students selected by means of a pre-test diagnostic questionnaire. Later, we compared them with a post-test questionnaire to assess the change in their conceptions regarding the knowledge worked upon during the didactic intervention. The proposal was carried out with third-year students in compulsory secondary education (ESO), as part of the Social Sciences course, $\mathrm{G}^{\mathrm{a}}$ and $\mathrm{H}^{\mathrm{a}}$, in which we worked on economic sectors. In a world immersed in globalization, where humanity's progress is closely linked to economic development, an understanding of how economic networks operate is crucial in order to comprehend how the world around us is 
formed. This includes the system of supply and demand, and the causes and consequences of territorial transformation and the criteria that govern it $[12,17,28-30]$.

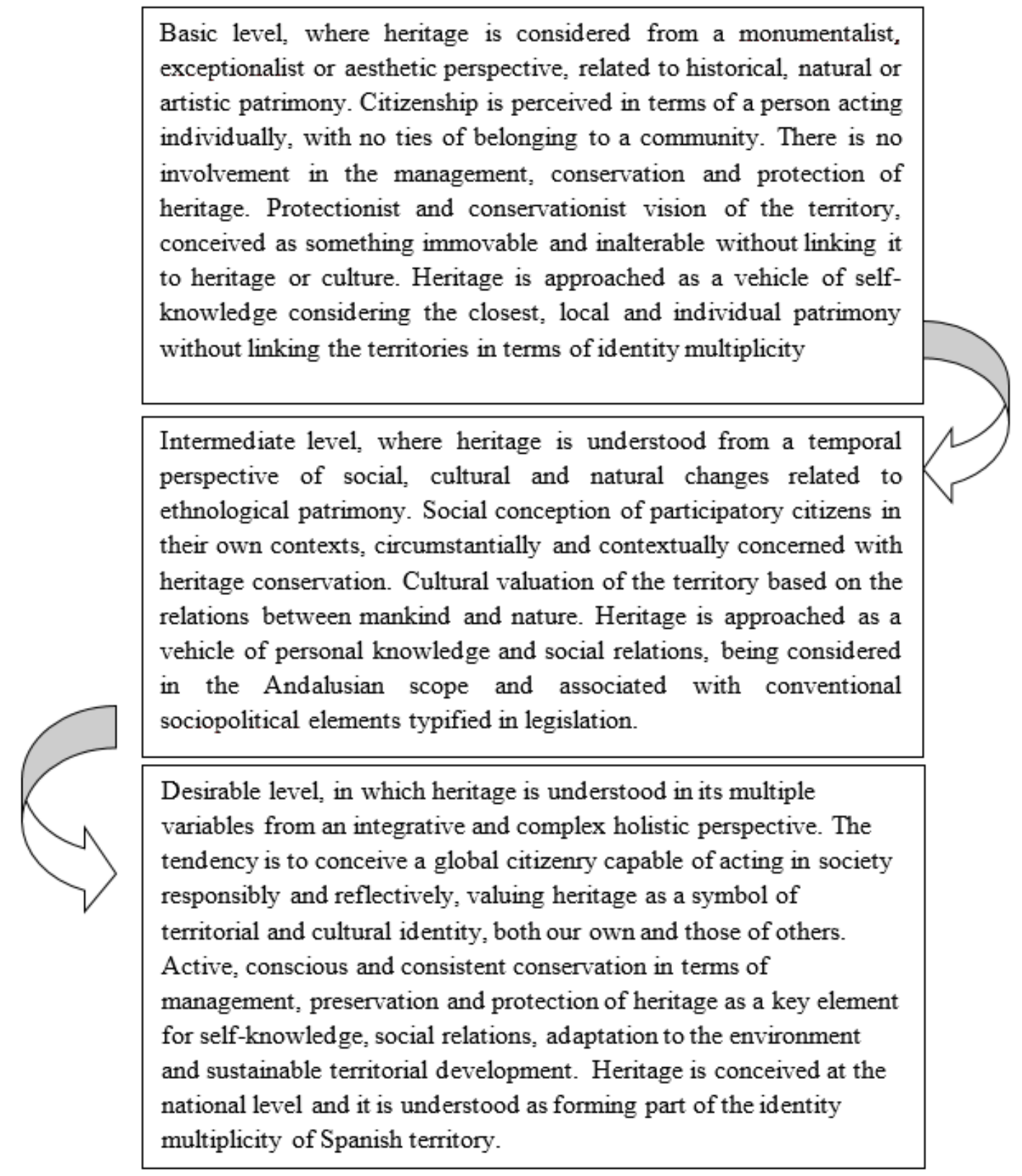

Figure 1. Progression hypothesis regarding heritage conceptions. Own creation based on Cuenca [26].

The choice of school and a teacher to take part in the experiment were conditioned by several factors. The school selected, El Galeón Secondary School, is a public institute located in the municipality of Isla Cristina, in the province of Huelva (Spain). The school has taken part in the Live and Feel Heritage (Live and Feel Heritage is an initiative framed within the National Education and Heritage Plan, approved in April 2013 by the Spanish Historical Heritage Council and up and running since 2016. It is a program for working on heritage from different standpoints, with the aim of encouraging the enjoyment, knowledge and understanding of historical, artistic, ethnographic, scientific and technical values of cultural assets. See http://www.juntadeandalucia.es/educacion/webportal/web/planes-yprogramas/vivir-y-sentir-el-patrimonio) initiative by the Autonomous Government of Andalusia since 2016, so has an important track record in heritage education. The teacher taking part in the study coordinates this program at the school, graduated with a doctorate in heritage education in 2013, 
and has been practicing as a teacher of Social Sciences, $\mathrm{G}^{\mathrm{a}}$ and $\mathrm{H}^{\mathrm{a}}$, since then in the selected center. In addition, the teacher actively collaborated in the research, agreeing on the working sessions and timing of the proposal with the students as part of the HETEIC project research team, within which the current study is framed. The teacher's previous training is essential for the development of this proposal, as they are involved in the process at all times. We selected a group of nineteen 3rd year secondary school pupils at a medium-low curricular level.

The choice of the didactic proposal around the tertiary sector was determined by several reasons. Isla Cristina is a locality with a long-standing seafaring tradition whose main economic resource is fishing. Because of this, we set out from the idea that to protect the material fishing heritage such as the port, the fish market, the boats, etc. and immaterial, such as salting industries, canning factories and fishing techniques transmitted from generations to generations, this patrimony must be acknowledged and identified as a symbol of identity. Secondly, we consider that heritage education designed to develop the students' territorial intelligence, focused on the understanding, reflection, and critical assessment of the factors that condition the development of their territory, to a great extent economic, reaches its peak in the work of didactic proposals focused on the knowledge of economic sectors in a globalized world.

As for the choice of the heritage institution, we selected the El Pintado Tide Mill Eco-Museum. The museum is situated in the Isla Cristina Marshlands Natural Park, a recently restored large saltwater tidal mill, dedicated to grinding using hydraulic milling technology. We chose this institution for several reasons: on one hand, the museum takes part in the project Nature and You (La Naturaleza y Tú / Nature and You. http://www.juntadeandalucia.es/educacion/portals/web/aldea/proyectos/lanaturaleza-y-tu/el-proyecto), an initiative designed to bring students closer to the natural environment in order to facilitate knowledge and dissemination of their heritage. On the other, the company responsible for managing the museum and educational activities is Spoonbills, Nature, and Heritage (http://www.platalea.com/), a business based in Huelva capital dedicated to natural and cultural tourism with a 13-year history. Finally, we interviewed the company chair, after which we detected a vision of heritage in line with our perspective, fulfilling parameters that can be considered good educational practices [31].

\subsection{Intervention/Experiment Description}

We designed a didactic proposal whose transversal axis is heritage and where the visit to the El Pintado Tide Mill Eco-Museum was the main focus. The proposal is based on interaction between patrimonial elements and the students, favoring working on heritage contents in the connection between school and museum. The theme of the unit is "The Tertiary Sector." The experiment was carried out over 13 hour-long work sessions (12 in the classroom and 1 research outing), three days a week.

The education proposal was developed following a methodological research and cooperative approach in which the students play an active part, taking the leading role in the construction of knowledge (organizing content; seeking, selecting, and contrasting information; data synthesis and analysis; presentation and dissemination of results). The research problem is proposed through investigation of the past and discovery and analysis of the present, following in this approach the line proposed by the curricular project Investigating our World [28]. The class dynamic consisted of five working groups that were offered the plan with basic questions on each of the services to be investigated. From the context of cooperative learning we have defined different techniques that served to support learning. The proposal was drafted representing the territorial, social, and cultural characteristics of the community related to heritage elements close to the students, taking into account the causes and consequences of territorial development based on the asset in question, favoring interdisciplinary knowledge insofar as it is worked upon from the standpoint of several disciplines, not only the historical, but also the economic, geographic, natural, or technological, and reflecting on different points of view with empathy in the configuration of a common and unified society. 
The teaching and learning process was structured in different phases: In the initial phase, planning, we examined the students' previous conceptions regarding heritage, territory, and citizenship. During this phase, the sectors studied are related to the gastronomic, ethnological, historical, monumental heritage, the territorial exploitation of natural spaces for cultivation or aquaculture techniques, as well as the social, cultural, and environmental consequences of development. The second phase, searching and structuring, covers the core of the process and constitutes the most extensive one, in which the student searches, investigates, analyzes, and solves the problems of the research process. Study of the evolution of the different tertiary sector services is proposed from a symbolic-identity perspective of heritage. Economic development is approached in terms of the changing and evolution of territories. It is in this phase that the research outing to the El Pintado Marshland Tide Mill Eco-Museum takes place, thus constituting one of the key activities in the reflection on the issues raised throughout the process. Finally, it culminates with the evaluation phase, in which students present the results of their research through different forms of communication and dissemination.

The aim of the didactic proposal is for the students to develop awareness of those aspects related with their environment and the impact their own actions have upon their surroundings. On the other hand, the intention is that they should understand heritage as a symbol of social, cultural and natural identity. A participatory citizenry that favors the protection, conservation, and dissemination of heritage, spearheading sustainable actions for sociocultural and environmental development.

\subsection{Research Methodology}

The research follows mixed study parameters [32]. We follow the parameters of the quantitative paradigm with the application of statistical and correlational methods to discover the relationships between the variables. This facilitates post hoc explanatory theories in a natural context. We then interpret the phenomena and understand the relationships between the variables through the qualitative paradigm [33].

The quasi-experimental study (transversal in nature, with a specific intervention period of three months) was carried out using pre-test and post-test questionnaires, without a control group. We used this model because the sample object of study came pre-established at the time of the study. After applying the pre-test, we administered the procedure with the experimental group and subsequently applied the post-test to compare the outcomes and pinpoint relevant changes in students' conceptions. This way, two different conditions (before and after the intervention) are necessary to establish the comparison between both times [34]. The study considered one independent variable and one dependent. The independent variable referred to the face-to-face modality and teaching methodology. The dependent variable corresponded to the increase in learning observed in the outcomes obtained when comparing the pre-test and post-test results.

For processing and statistical analysis of the data, we used the SPSS (Statistical Package for the Social Sciences) program, through a system of categories organized around the progression of knowledge in each of them, taking as a model the works of Cuenca, Estepa, and Martín-Cáceres [18] (See Table 1).

To gather the information, we used a semi-structured questionnaire consisting of 7 questions (open and closed). To ensure the success of the issues proposed in the study, we conducted a first questionnaire as a pilot trial in a different course, but with similar features, to corroborate whether the questions were asked with sufficient clarity and ensure there were no obstacles to its development, with consistency between the possible responses and the analysis categories (Table 1). 
Table 1. Table of categories for information analysis. Own development.

\begin{tabular}{|c|c|c|c|}
\hline CATEGORIES & SUB-CATEGORIES & INDICATORS & DESCRIPTORS \\
\hline \multirow{9}{*}{ HERITAGE } & \multirow{5}{*}{$\begin{array}{l}\text { Heritage } \\
\text { perspective }\end{array}$} & $\begin{array}{c}\text { Fetishist- } \\
\text { exceptionalist }\end{array}$ & $\begin{array}{l}\text { Irrational admiration, exceptionalism, amulet concept, object } \\
\text { of worship. }\end{array}$ \\
\hline & & Monumentalist & $\begin{array}{c}\text { Spectacularity and acknowledged prestige of material or } \\
\text { immaterial elements. }\end{array}$ \\
\hline & & Aesthetic & $\begin{array}{c}\text { Admiration for physical features and material wealth } \\
\text { of heritage. }\end{array}$ \\
\hline & & Temporal & $\begin{array}{c}\text { Evolutionary-temporal character of natural changes, } \\
\text { relict species. }\end{array}$ \\
\hline & & Symbolic-identity. & $\begin{array}{c}\begin{array}{c}\text { Symbolic elements of a society, natural surroundings or } \\
\text { geo-biodiversity. }\end{array}\end{array}$ \\
\hline & \multirow{4}{*}{ Heritage typology } & $\begin{array}{l}\text { Natural } \\
\text { Artistic }\end{array}$ & $\begin{array}{l}\text { Aspects of an environmental nature. } \\
\text { Manifestations of artistic movements. }\end{array}$ \\
\hline & & $\begin{array}{l}\text { Scientific- } \\
\text { technological }\end{array}$ & Industrial components of sociocultural relevance. \\
\hline & & Ethnological & $\begin{array}{l}\text { Meaningful and traditional elements that explain social } \\
\text { cultural and territorial change. }\end{array}$ \\
\hline & & $\begin{array}{l}\text { Historical } \\
\text { Holistic }\end{array}$ & $\begin{array}{l}\text { Archaeological and documentary references. } \\
\text { Global and unified consideration of the above manifestations. }\end{array}$ \\
\hline \multirow{6}{*}{ CITIZENS } & \multirow{3}{*}{$\begin{array}{c}\text { Citizen } \\
\text { participation }\end{array}$} & $\begin{array}{l}\text { Personally } \\
\text { responsible citizen }\end{array}$ & $\begin{array}{l}\text { Acts in a responsible manner in the community, collecting } \\
\text { rubbish, recycling, etc. Works and pays taxes, obeys laws and } \\
\text { helps those in need. }\end{array}$ \\
\hline & & Participative citizen & $\begin{array}{l}\text { Active member of organizations and/or initiatives for } \\
\text { community improvement. Knows the strategies for carrying } \\
\text { out collective tasks, encourages economic development or } \\
\text { cleans up the environment. }\end{array}$ \\
\hline & & $\begin{array}{l}\text { Justice-oriented } \\
\text { citizen }\end{array}$ & $\begin{array}{l}\text { Assesses social, political and economic structures to see } \\
\text { beyond superficial causes; seeks and confronts the areas } \\
\text { where injustice prevails; is aware of social movements and } \\
\text { how to carry out systemic changes. }\end{array}$ \\
\hline & \multirow{3}{*}{$\begin{array}{l}\text { Concept of } \\
\text { citizenship }\end{array}$} & Individualist & $\begin{array}{l}\text { Responsible citizen aware of his/her rights, with sense of } \\
\text { belonging to a community. May take part individually in } \\
\text { initiatives led and driven by other people. }\end{array}$ \\
\hline & & Social & $\begin{array}{l}\text { Participative citizen aware of his/her individual rights and } \\
\text { responsibilities to the community. May lead or promote the } \\
\text { functioning of organisations and/or initiatives related to their } \\
\text { specific context. }\end{array}$ \\
\hline & & Global & $\begin{array}{c}\text { Citizen of the world and committed to justice that respects } \\
\text { and values interculturality. Questions and collaborates in the } \\
\text { transformation of structures and systems that } \\
\text { reproduce injustice. }\end{array}$ \\
\hline \multirow{6}{*}{$\begin{array}{l}\text { TERRITORIAL } \\
\text { INTELLIGENCE }\end{array}$} & \multirow{3}{*}{$\begin{array}{c}\text { Territorial } \\
\text { development }\end{array}$} & $\begin{array}{l}\text { Protectionist- } \\
\text { conservationist }\end{array}$ & $\begin{array}{l}\text { Importance of conserving heritage as a legacy for future } \\
\text { generations, developing citizen procedures to this end. }\end{array}$ \\
\hline & & Cultural & \\
\hline & & Sustainable & $\begin{array}{l}\text { Global citizen, critical and active with their surroundings. } \\
\text { Perception of human interactions with nature and their } \\
\text { consequences. Proposes lines of action for environmental } \\
\text { balance and sustainable economic development. }\end{array}$ \\
\hline & \multirow{3}{*}{$\begin{array}{l}\text { Heritage } \\
\text { conservation } \\
\text { management }\end{array}$} & Non-interventionist & $\begin{array}{l}\text { Passivity regarding the conservation of heritage as a factor for } \\
\text { sustainable territorial development. }\end{array}$ \\
\hline & & Circumstantial & $\begin{array}{c}\text { Heritage conservationist attitude. Self-centered and } \\
\text { contextual vision of sustainable development without } \\
\text { awareness of the need for communication and cooperation } \\
\text { with other social agents. }\end{array}$ \\
\hline & & $\begin{array}{l}\text { Conscious and } \\
\text { consequent }\end{array}$ & $\begin{array}{l}\text { Awareness of the territory as collective patrimony on which } \\
\text { we depend biologically and culturally.Active participation in } \\
\text { heritage management as a symbolic-identity element, } \\
\text { promoting ways of acting with different social agents for its } \\
\text { conservation as a key element in territorial planning to } \\
\text { achieve sustainable management of resources and protection } \\
\text { of biodiversity. }\end{array}$ \\
\hline
\end{tabular}

\section{Analysis and Discussion of Results}

We performed an explanatory descriptive analysis that shows, on the one hand, the results in percentages assigned to the differences between the particular items of each question, distinguishing 
between pre-test and post-test. On the other, we present the results in terms of the degree of evolution of the students' conceptions.

Question 1 results (Table 2, Figures 2 and 3): From the options proposed below, please mark with an $\mathrm{X}$ the elements you consider heritage and which symbolize a culture, society, etc.

Table 2. Question 1: Analysis results on the degree of concept evolution. (I Basic level/II Intermediate level/III Desirable level).

\begin{tabular}{lcccccc}
\hline Time & \multicolumn{2}{c}{$\begin{array}{c}\text { Degree of Concept } \\
\text { Evolution }\end{array}$} & Frequency & Percentage & $\begin{array}{c}\text { Valid } \\
\text { Percentage }\end{array}$ & $\begin{array}{c}\text { Accumulated } \\
\text { Percentage }\end{array}$ \\
\hline \multirow{3}{*}{ Pre-test } & \multirow{2}{*}{ Valid } & Basic & 11 & 57.9 & 57.9 & 57.9 \\
\cline { 3 - 7 } & & Intermediate & 8 & 42.1 & 42.1 & 100.0 \\
\cline { 3 - 7 } & \multirow{3}{*}{ Post-test } & Total & 19 & 100.0 & 100.0 & \\
& \multirow{2}{*}{ Valid } & Intermediate & 11 & 57.9 & 57.9 & 57.9 \\
\cline { 3 - 7 } & & Desirable & 8 & 42.1 & 42.1 & 100.0 \\
\hline & & Total & 19 & 100.0 & 100.0 & \\
\hline
\end{tabular}

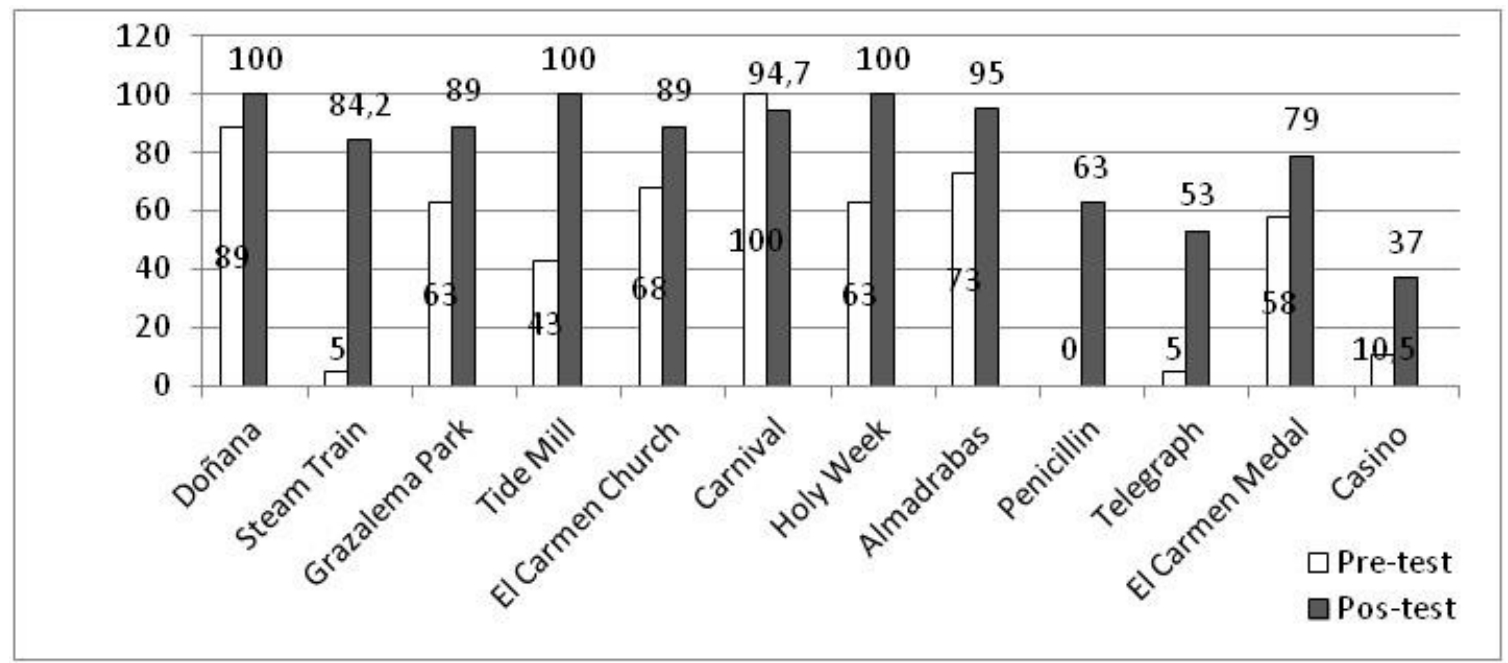

Figure 2. Question 1: From the options proposed below, please mark with an $\mathrm{X}$ the elements you consider heritage and which symbolize a culture, society, etc.

The data show a clear evolution in the students' conceptions. The success of the intervention is clear in that we observe a clear evolution from the basic and intermediate level in pre-test to the intermediate and desirable level in post-test. One rather significant outcome is the number of students that evolved from one level to the other, with the same number going from basic to intermediate level and from intermediate to desirable level. In post-test, we find a certain recognition of scientific-technological heritage, non-existent in the pre-test phase, such as the discovery of penicillin, which went from not being considered heritage to scoring $63 \%$ after the intervention; or the case of the steam train, which rose from $5 \%$ to $84 \%$, as well as other cases such as the telegraph or the tidal mill. Another significant fact is the lower frequency of choosing "the Carnival" as a symbol of heritage identification, scoring $100 \%$ in the pre-test and falling to $97.4 \%$ in the post-test. This could be subject to a student changing their idea after the didactic experiment, considering this event less relevant. The identification of these elements as heritage is determined by the students' involvement in the task when working on the didactic proposal. When working on economic sectors from the heritage standpoint, the pupils were able to observe the evolution of the means of transport and healthcare techniques with the most important scientific breakthroughs that laid the foundations of health as we know it today. 
However, when we asked the pupils freely about other aspects they considered heritage and culturally symbolic, we found that this evolution towards the desirable level did not occur (Table 3 and Figure 3). The evolution, in this case, was from level I to II, with greater presence of ethnological heritage, such as traditions and festivities or gastronomy. In the post-test results, the impact of the teaching itineraries can be appreciated, represented by the Eco-Museum, marshlands, or salt works as heritage elements. The same case is represented in the selection of items related to leisure, celebrations, and craft traditions, such as fishing techniques.

Table 3. Question 1.1: “Other patrimonial elements you consider Heritage and which symbolize a culture". Results of analysis on degree of concept evolution. (I Basic level/II Intermediate level/III Desirable level).

\begin{tabular}{|c|c|c|c|c|c|c|}
\hline Time & & Degree of Concept Evolution & Frequency & Percentage & $\begin{array}{c}\text { Valid } \\
\text { Percentage }\end{array}$ & $\begin{array}{l}\text { Accumulated } \\
\text { Percentage }\end{array}$ \\
\hline \multirow{4}{*}{ Pre-test } & \multirow{4}{*}{ Valid } & Basic & 11 & 57.9 & 57.9 & 57.9 \\
\hline & & Intermediate & 4 & 21.1 & 21.1 & 78.9 \\
\hline & & No Answer or Not Applicable & 4 & 21.1 & 21.1 & 100.0 \\
\hline & & Total & 19 & 100.0 & 100.0 & \\
\hline \multirow{4}{*}{ Post-test } & \multirow{4}{*}{ Valid } & Basic & 8 & 42.1 & 42.1 & 42.1 \\
\hline & & Intermediate & 6 & 31.6 & 31.6 & 73.7 \\
\hline & & No Answer or Not Applicable & 5 & 26.3 & 26.3 & 100.0 \\
\hline & & Total & 19 & 100.0 & 100.0 & \\
\hline
\end{tabular}
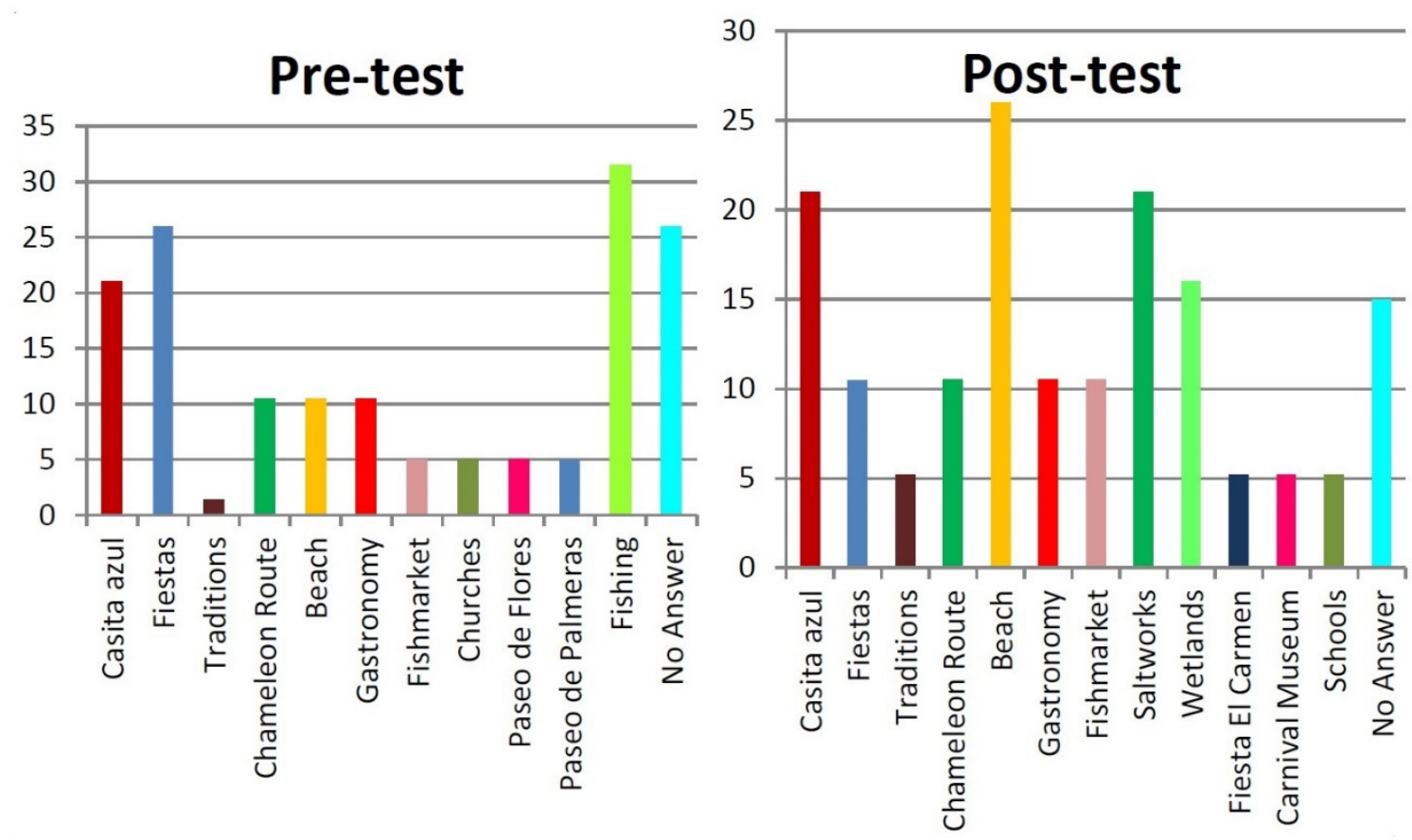

Figure 3. Question 1.1: Other elements considered heritage and which symbolize a culture.

Question 2 results (Table 4, Figures 4 and 5): Mark with an X the importance that the following cultural and natural elements have for you. 
Table 4. Question 2 results: (I Basic level/II Intermediate level/III Desirable level).

\begin{tabular}{|c|c|c|c|c|c|c|}
\hline Time & Deg & oncept Evolution & Frequency & Percentage & $\begin{array}{c}\text { Valid } \\
\text { Percentage }\end{array}$ & $\begin{array}{l}\text { Accumulated } \\
\text { Percentage }\end{array}$ \\
\hline \multirow{3}{*}{ Pre-test } & \multirow{3}{*}{ Valid } & Basic & 5 & 26.3 & 26.3 & 26.3 \\
\hline & & Intermediate & 14 & 73.7 & 73.7 & 100.0 \\
\hline & & Total & 19 & 100.0 & 100.0 & \\
\hline \multirow{3}{*}{ Post-test } & \multirow{3}{*}{ Valid } & Intermediate & 8 & 42.1 & 42.1 & 42.1 \\
\hline & & Desirable & 11 & 57.9 & 57.9 & 100.0 \\
\hline & & Total & 19 & 100.0 & 100.0 & \\
\hline
\end{tabular}

After the intervention, a clear evolution was observed in terms of awareness of the importance of patrimonial elements which the majority of students claimed not to know in the pre-test phase. This is the case of scientific heritage, such as scientific breakthroughs, and technological heritage such as the canoe, the microscope, or the steamboat, which went from being unknown to being deemed important or very important. In the case of the conceptual evolution, we find that after the intervention, none of the students remained at level I, with the desirable level predominating after the process. This highlights the efficacy of the teaching and learning process, as the consideration of heritage in its multiple perspectives took place after the didactic proposal.

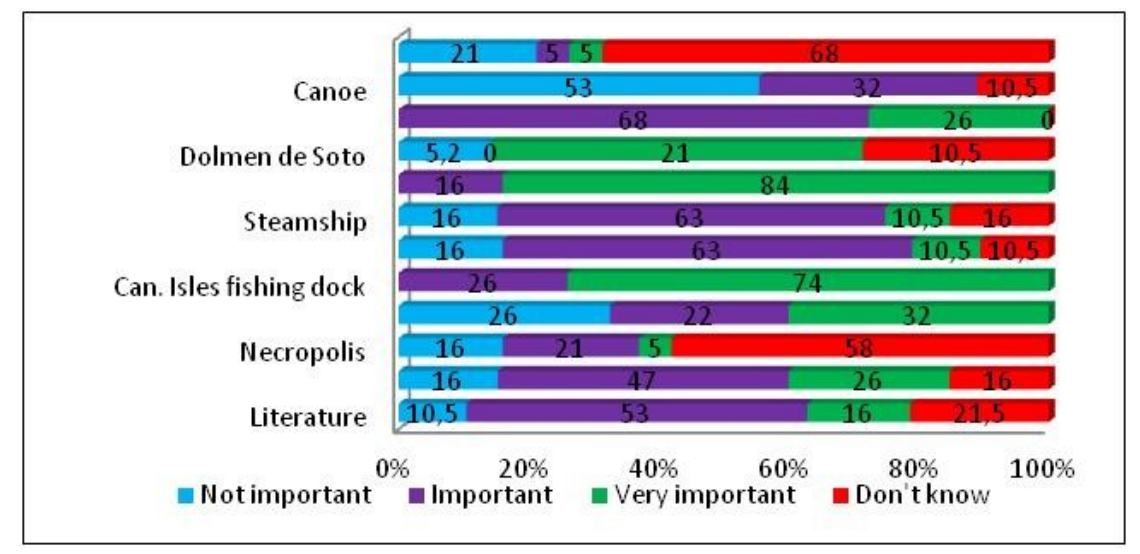

Figure 4. Question 2 Pre-test.

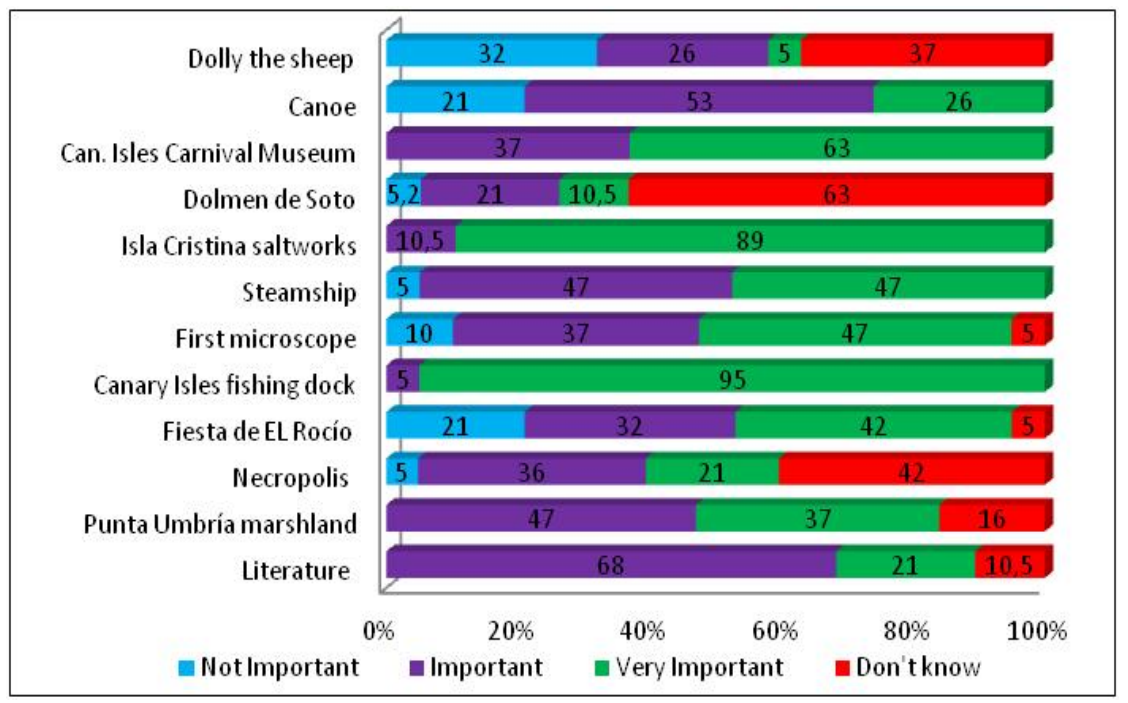

Figure 5. Question 2 Post-test. 
Question 3 results: Imagine you are a primary teacher. What would you teach? Mark with an $\mathrm{X}$ according to the importance given to each item (Tables 5-7, Figure 6).

Table 5. Results of analysis on the degree of concept evolution. (I Basic level/II Intermediate level/III Desirable level).

\begin{tabular}{|c|c|c|c|c|c|c|}
\hline \multicolumn{7}{|c|}{ Relation with Heritage Education } \\
\hline Time & & $\begin{array}{l}\text { f Concept } \\
\text { ution }\end{array}$ & Frequency & Percentage & $\begin{array}{c}\text { Valid } \\
\text { Percentage }\end{array}$ & $\begin{array}{l}\text { Accumulated } \\
\text { Percentage }\end{array}$ \\
\hline \multirow{4}{*}{ Pre-test } & \multirow{4}{*}{ Valid } & Basic & 2 & 10.5 & 10.5 & 10.5 \\
\hline & & Intermediate & 11 & 57.9 & 57.9 & 68.4 \\
\hline & & Desirable & 6 & 31.6 & 31.6 & 100.0 \\
\hline & & Total & 19 & 100.0 & 100.0 & \\
\hline Post-test & Valid & Desirable & 19 & 100.0 & 100.0 & 100.0 \\
\hline
\end{tabular}

Table 6. Results of analysis on the degree of concept evolution. (I Basic level/II Intermediate level/III Desirable level).

\begin{tabular}{|c|c|c|c|c|c|c|}
\hline \multicolumn{7}{|c|}{ Relation with Citizenship } \\
\hline Time & De & $\begin{array}{l}\text { f Concept } \\
\text { lution }\end{array}$ & Frequency & Percentage & $\begin{array}{c}\text { Valid } \\
\text { Percentage }\end{array}$ & $\begin{array}{l}\text { Accumulated } \\
\text { Percentage }\end{array}$ \\
\hline \multirow{4}{*}{ Pre-test } & \multirow{4}{*}{ Valid } & Basic & 1 & 5.3 & 5.3 & 5.3 \\
\hline & & Intermediate & 13 & 68.4 & 68.4 & 73.7 \\
\hline & & Desirable & 5 & 26.3 & 26.3 & 100.0 \\
\hline & & Total & 19 & 100.0 & 100.0 & \\
\hline \multirow{3}{*}{ Post-test } & \multirow{3}{*}{ Valid } & Intermediate & 9 & 47.4 & 47.4 & 47.4 \\
\hline & & Desirable & 10 & 52.6 & 52.6 & 100.0 \\
\hline & & Total & 19 & 100.0 & 100.0 & \\
\hline
\end{tabular}

Table 7. Results of analysis on the degree of concept evolution. (I Basic level/II Intermediate level/III Desirable level).

\begin{tabular}{|c|c|c|c|c|c|c|}
\hline \multicolumn{7}{|c|}{ Relation with Territorial Intelligence } \\
\hline Time & & $\begin{array}{l}\text { Concept } \\
\text { lution }\end{array}$ & Frequency & Percentage & $\begin{array}{c}\text { Valid } \\
\text { Percentage }\end{array}$ & $\begin{array}{l}\text { Accumulated } \\
\text { Percentage }\end{array}$ \\
\hline \multirow{4}{*}{ Pre-test } & \multirow{4}{*}{ Valid } & Basic & 2 & 10.5 & 10.5 & 10.5 \\
\hline & & Intermediate & 15 & 78.9 & 78.9 & 89.5 \\
\hline & & Desirable & 2 & 10.5 & 10.5 & 100.0 \\
\hline & & Total & 19 & 100.0 & 100.0 & \\
\hline \multirow{3}{*}{ Post-test } & \multirow{3}{*}{ Valid } & Intermediate & 11 & 57.9 & 57.9 & 57.9 \\
\hline & & Desirable & 8 & 42.1 & 42.1 & 100.0 \\
\hline & & Total & 19 & 100.0 & 100.0 & \\
\hline
\end{tabular}

We observe that the basic level no longer features in post-test and the students' answers are distributed between the intermediate and desirable levels. The evolution towards level III relative to the concept of heritage is seen in the consideration of traditional elements as symbolic identity elements during the post-test phase. Moreover, in the territorial intelligence category, we observe this evolution in the consideration in post-test of the importance of conserving and protecting heritage consciously and focused on sustainable development of the territory (protecting the environment, the ecological consequences of transport). 
Not Important Important Very Important

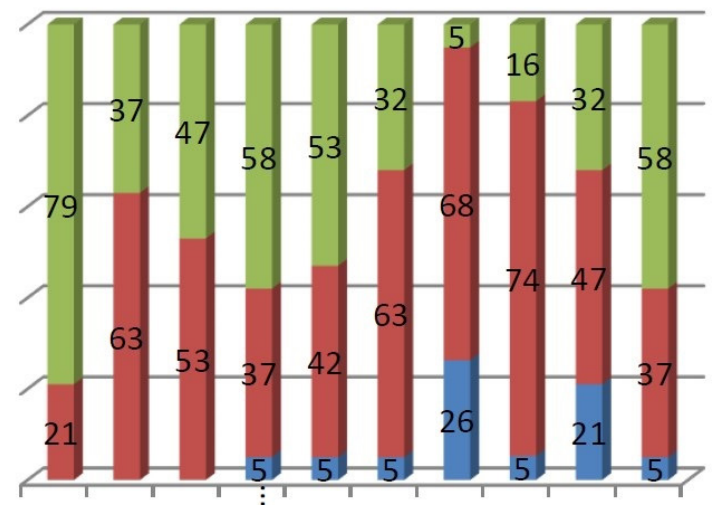

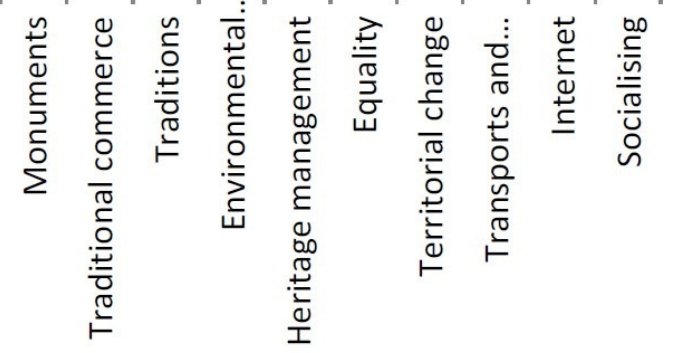

Not Important $\quad$ Important $\square$ Very important

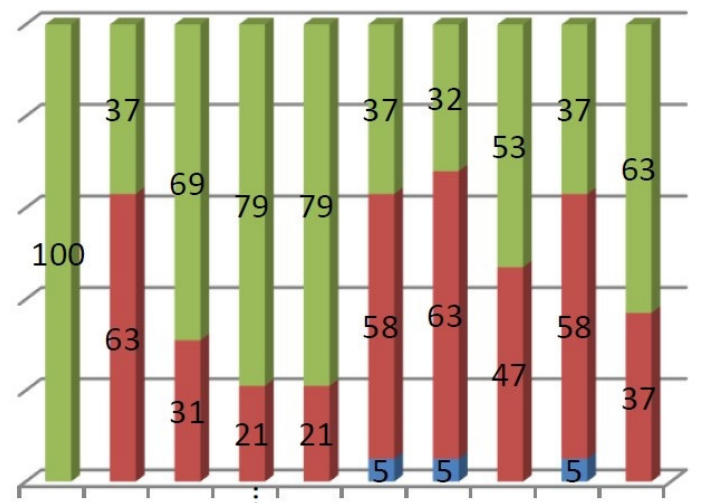

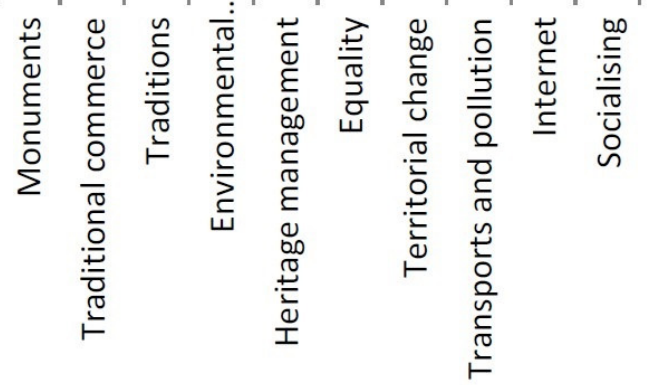

Figure 6. Question 3.

When questioning them freely about other knowledge considered important, (Table 8) we found that, compared to the pre-test, only four students answered, pointing out issues such as respecting the environment and teamwork. In post-test, we observed that the participation increased considerably, evidencing the efficacy of the intervention. Their answers show the relevance for students of those the aspects related to interpersonal relationships, highlighting issues such as respecting turn-taking, knowing how to talk to the teacher, respecting the preferences of others, raising awareness about equality, or respecting each other. The identification of these items as relevant may be due to the methodological process that was implemented during the unit. Through cooperative and collaborative work, the students had to coordinate themselves and work as a team, thus illustrating the importance of interpersonal relationships on the path to becoming good global citizens. On the other hand, other students highlighted the importance of tourism and the economy, as well as knowing local history, contents worked upon as part of the unit. This is an open question that does not require the student to respond and no items are provided that condition it, which is why the results are successful, showing a higher rate of participation and evolution of the degrees of progression of learning.

Table 8. Results of analysis on the degree of concept evolution. (I Basic level/II Intermediate level/III Desirable level).

\begin{tabular}{|c|c|c|c|c|c|c|}
\hline \multicolumn{7}{|c|}{ Other Important Knowledge } \\
\hline Time & & egree of Concept Evolution & Frequency & Percentage & $\begin{array}{c}\text { Valid } \\
\text { Percentage }\end{array}$ & $\begin{array}{l}\text { Accumulated } \\
\text { Percentage }\end{array}$ \\
\hline \multirow{3}{*}{ Pre-test } & \multirow{3}{*}{ Valid } & Desirable & 2 & 10.5 & 10.5 & 10.5 \\
\hline & & No Answer or Not Applicable & 17 & 89.5 & 89.5 & 100.0 \\
\hline & & Total & 19 & 100.0 & 100.0 & \\
\hline \multirow{4}{*}{ Post-test } & \multirow{4}{*}{ Valid } & Basic & 2 & 10.5 & 10.5 & 10.5 \\
\hline & & Desirable & 6 & 31.6 & 31.6 & 42.1 \\
\hline & & No Answer or Not Applicable & 11 & 57.9 & 57.9 & 100.0 \\
\hline & & Total & 19 & 100.0 & 100.0 & \\
\hline
\end{tabular}


Question 4: You are the mayor of your town or city and have to implement an economic development project. Choose by order of importance: Not very, Not at all, or Very (Table 9, Figures 7 and 8).

The content of this question is related to category III. The objective is to analyze what the students prioritize in relation to the conservation, protection, and dissemination of heritage, as well as issues related to sustainable development and environmental protection. Again, we see how the evolution towards the desirable level takes place after the intervention. The rating given to each item proposed in the post-test survey highlights greater awareness in this regard of the importance of conservation, protection, and conscious and consistent dissemination of heritage, as well as the need for sustainable development of their locality. We observed the rise in importance of issues such as creating beach cleaning companies, cultural itinerary schedules, promoting local trade, protecting the natural park, or financing non-polluting transport. On the other hand, we observed that the percentage degree of acceptance of items such as building a hotel in the marshlands decreased following the intervention. Again, we can see the impact and success of the intervention among the pupils. Learning is appreciated regarding the training of a citizenry that is the protagonist of change. Citizens who critically assess social, economic, and political structures with initiative to carry out systemic changes in the respect and appreciation of their environment with commitment to responsible action on the same.

Table 9. Results of analysis on the degree of concept evolution. (I Basic level/II Intermediate level/III Desirable level).

\begin{tabular}{ccccccc}
\hline Time & Degree of Concept Evolution & Frequency & Percentage & $\begin{array}{c}\text { Valid } \\
\text { Percentage }\end{array}$ & $\begin{array}{c}\text { Accumulated } \\
\text { Percentage }\end{array}$ \\
\hline \multirow{3}{*}{ Pre-test } & & Basic & 2 & 10.5 & 10.5 & 10.5 \\
& \multirow{2}{*}{ Valid } & Intermediate & 10 & 52.6 & 52.6 & 63.2 \\
& & Desirable & 7 & 36.8 & 36.8 & 100.0 \\
\cline { 3 - 6 } Post-test & & Total & 19 & 100.0 & 100.0 & 10.5 \\
& \multirow{2}{*}{ Valid } & Intermediate & 2 & 10.5 & 10.5 & 100.0 \\
& & Desirable & 17 & 89.5 & 89.5 & 100.0 \\
\hline
\end{tabular}

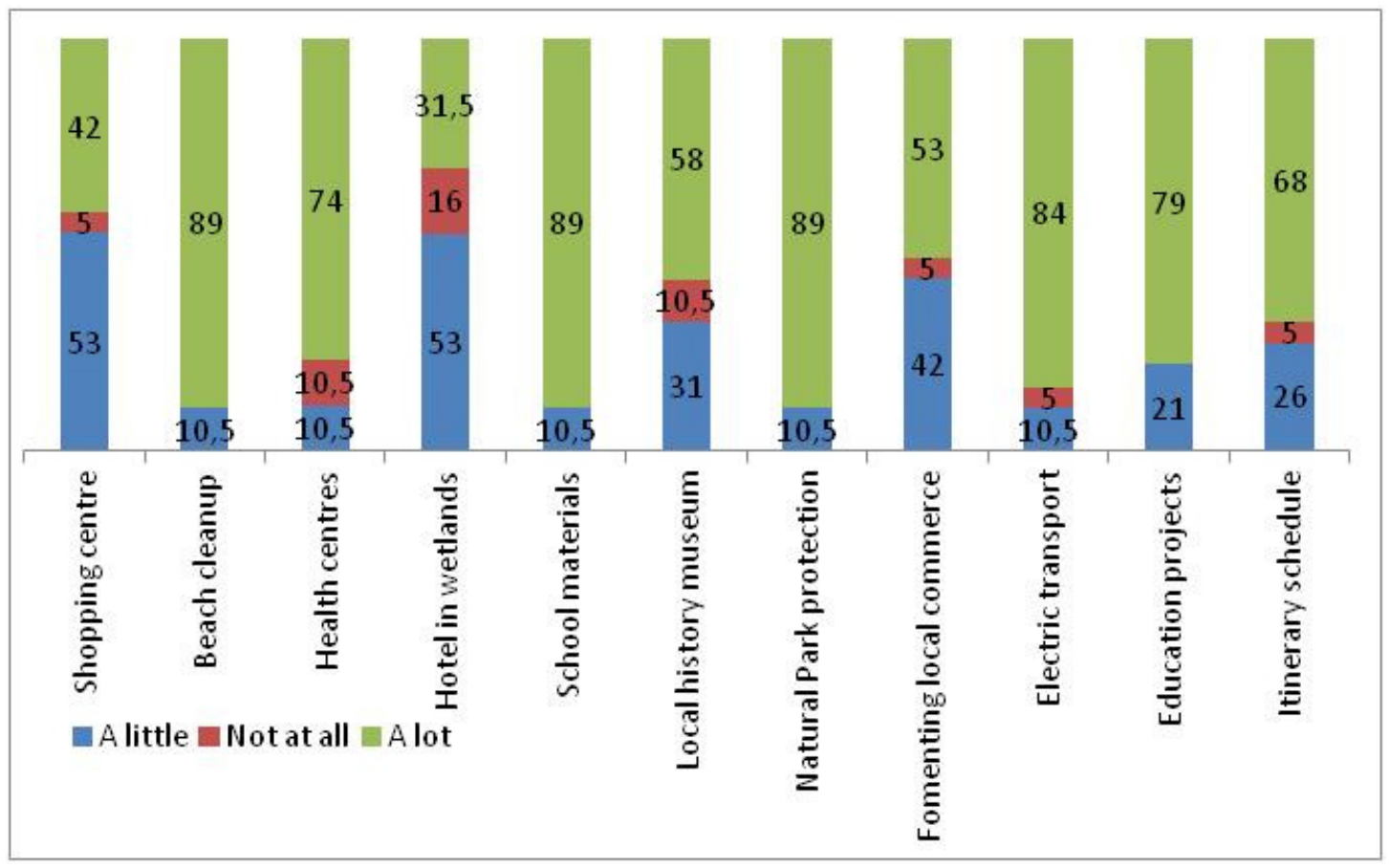

Figure 7. Question 4. Pre-test results. 


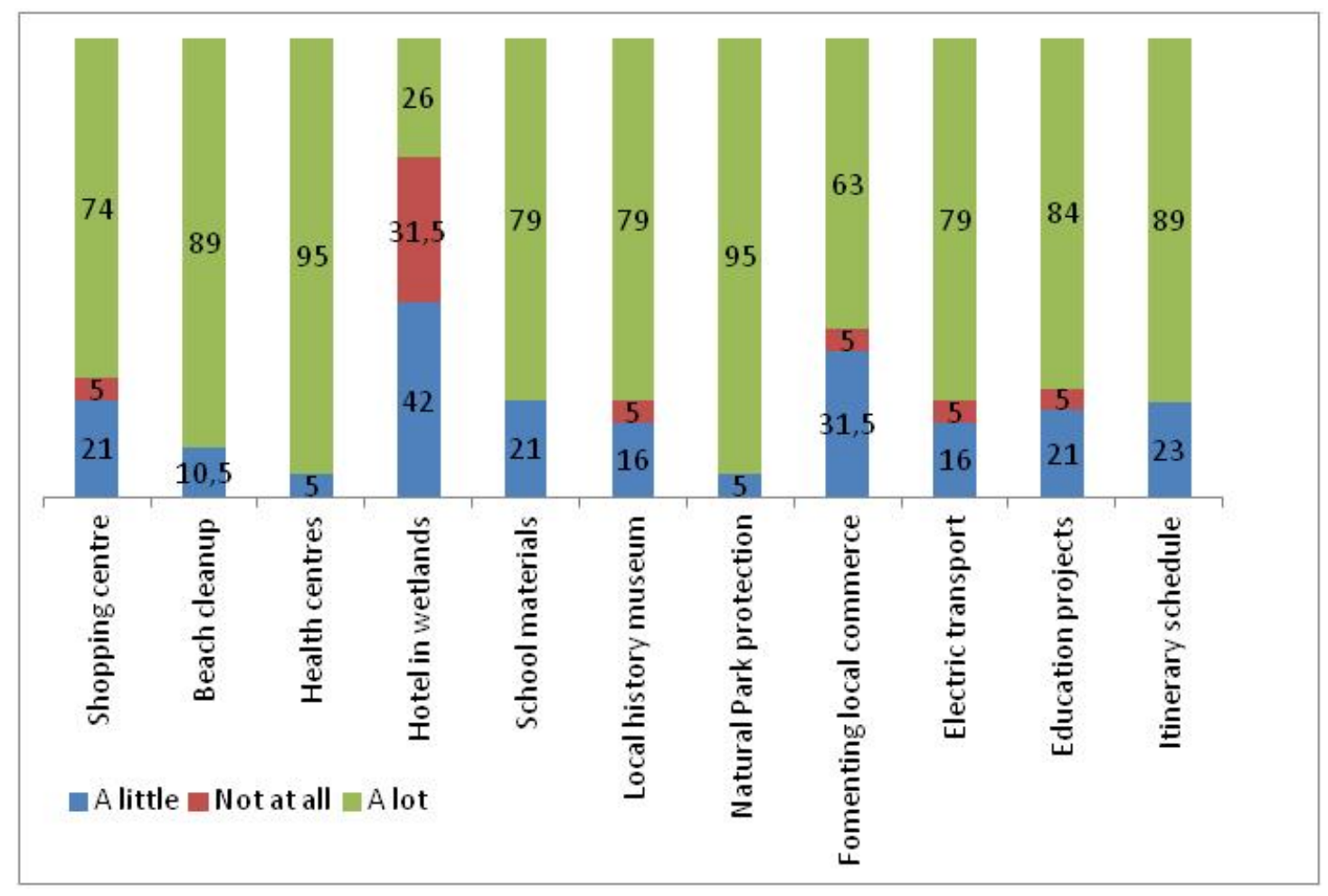

Figure 8. Question 4. Post-test results.

Question 5: Beach bars are being built opposite the Marismas del Odiel nature Park, just a few meters from the estuary waters. Mark with an $X$ those indicators with which you agree (Table 10 and Figure 9).

Table 10. Results of analysis on the degree of concept evolution. (I Basic level/II Intermediate level/III Desirable level).

\begin{tabular}{|c|c|c|c|c|c|c|}
\hline Time & Degree o & ncept Evolution & Frequency & Percentage & $\begin{array}{c}\text { Valid } \\
\text { Percentage }\end{array}$ & $\begin{array}{l}\text { Accumulated } \\
\text { Percentage }\end{array}$ \\
\hline \multirow{4}{*}{ Pre-test } & \multirow{4}{*}{ Valid } & Basic & 12 & 63.2 & 63.2 & 63.2 \\
\hline & & Intermediate & 3 & 15.8 & 15.8 & 78.9 \\
\hline & & Desirable & 4 & 21.1 & 21.1 & 100.0 \\
\hline & & Total & 19 & 100.0 & 100.0 & \\
\hline \multirow{4}{*}{ Post-test } & \multirow{4}{*}{ Valid } & Basic & 8 & 42.1 & 42.1 & 42.1 \\
\hline & & Intermediate & 3 & 15.8 & 15.8 & 57.9 \\
\hline & & Desirable & 8 & 42.1 & 42.1 & 100.0 \\
\hline & & Total & 19 & 100.0 & 100.0 & \\
\hline
\end{tabular}

This question is closely linked to the conception and participation of citizens as well as the capacity for critical, reflective, responsible, and committed action of the students regarding the sustainable development of the territory where they live. To this end, they were asked to consider the dilemma of the construction of a leisure tourism infrastructure on the territory of the natural landscape. We observed that the concepts of the pupils regarding this situation changed after the intervention insofar as we observed that evolution from basic to desirable level took place. In the post-test analysis, we noticed that the number of students who thought this was a good idea had decreased, with an increase in the percentage of members positioning themselves against its construction, advocating starting a campaign for its transfer. The percentage difference between the two measures is not extraordinary, but it is enough to appreciate the development of an awareness of the need to protect the natural environment in which we live. 


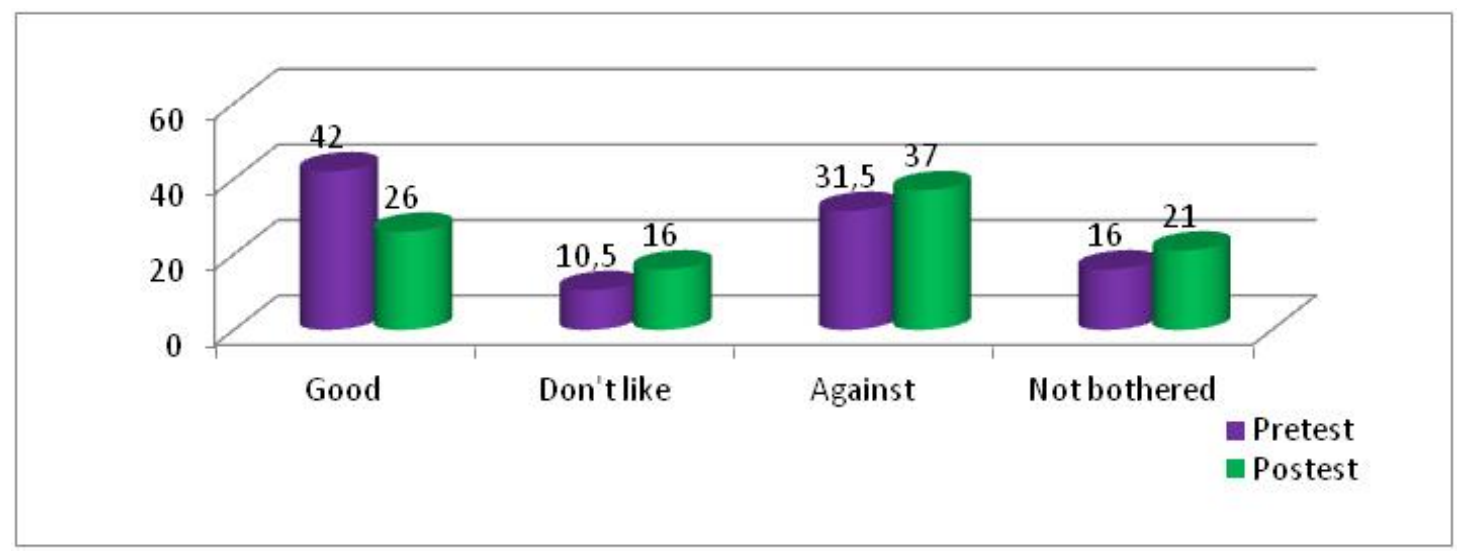

Figure 9. Question 5. Results.

Question $n^{\circ}$ 6: Imagine you have a foreign friend who is coming to your city. What would you recommend they visit? May be your area or Andalusia in general (Table 11, Figures 10 and 11).

Table 11. Results of analysis on the degree of concept evolution. (I Basic level/II Intermediate level/III Desirable level).

\begin{tabular}{|c|c|c|c|c|c|c|}
\hline Time & Degree o & cept Evolution & Frequency & Percentage & $\begin{array}{c}\text { Valid } \\
\text { Percentage }\end{array}$ & $\begin{array}{l}\text { Accumulated } \\
\text { Percentage }\end{array}$ \\
\hline \multirow{3}{*}{ Pre-test } & \multirow{3}{*}{ Valid } & Basic & 17 & 89.5 & 89.5 & 89.5 \\
\hline & & Intermediate & 2 & 10.5 & 10.5 & 100.0 \\
\hline & & Total & 19 & 100.0 & 100.0 & \\
\hline \multirow{4}{*}{ Post-test } & \multirow{4}{*}{ Valid } & Basic & 6 & 31.6 & 31.6 & 31.6 \\
\hline & & Intermediate & 10 & 52.6 & 52.6 & 84.2 \\
\hline & & Desirable & 3 & 15.8 & 15.8 & 100.0 \\
\hline & & Total & 19 & 100.0 & 100.0 & \\
\hline
\end{tabular}

The aim of this question is to reveal which heritage perspective they have and with which type of patrimony they identify the most. To do so, we asked them about aspects of their locality and autonomous community that they would recommend visiting. We observed that evolution took place from the basic level, in which monumental or natural heritage elements stood out, to the desirable level, considering patrimonial spaces from an integrated perspective, taking in all heritage typologies. In post-test, we see that the answers of the students are dispersed to a lesser extent so that they become more uniform, rating more common elements more frequently. The incidence of the didactic itineraries is observed insofar as they are reflected in post-test as fundamental elements that must be visited, appearing represented by $37 \%$ in the case of the El Pintado Eco-Museum, which did not appear in pre-test, and rising from $5 \%$ to $20 \%$ in post-test in the case of the salt works. The fishing port was considered an element of the town's identity in pre-test by $10.5 \%$ of the pupils. In this case, we also observed an increase in its recognition by students, up to $35 \%$. 


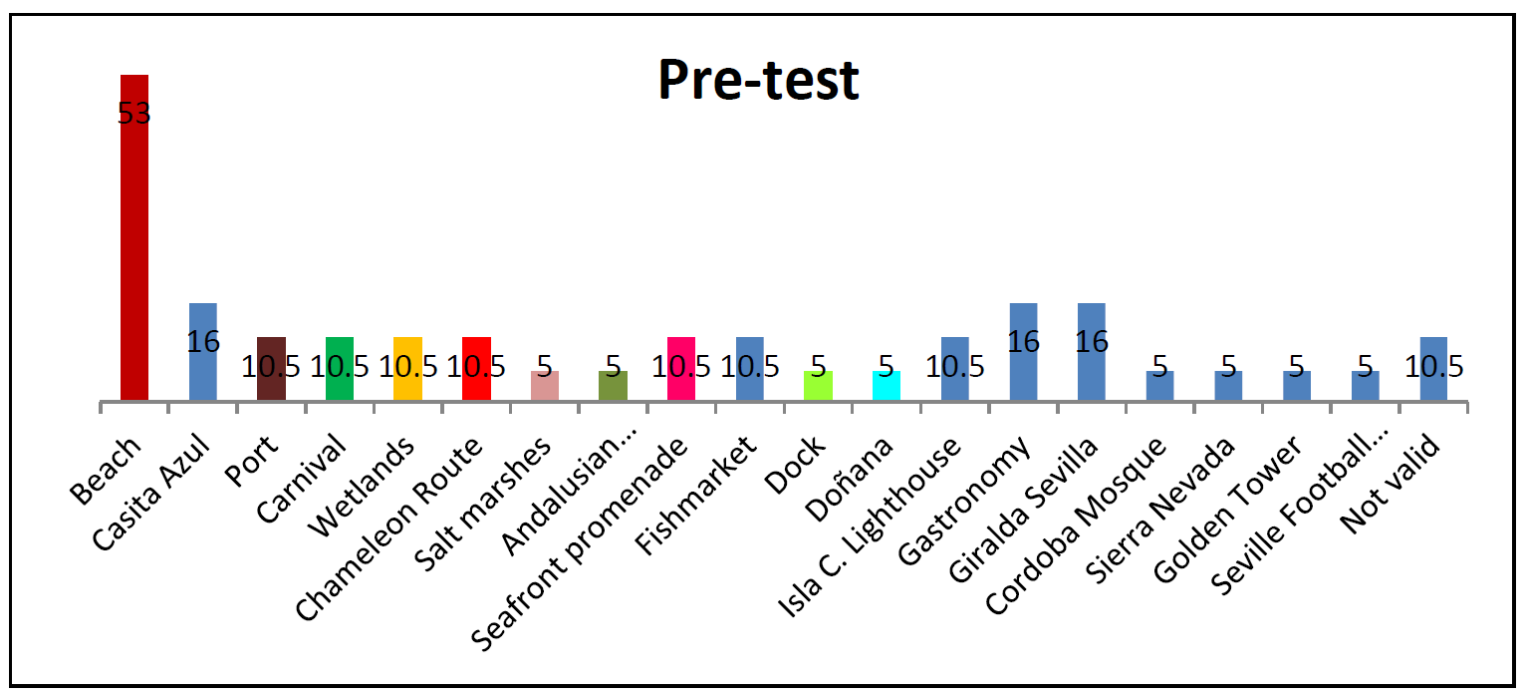

Figure 10. Question 6. Pre-test results.

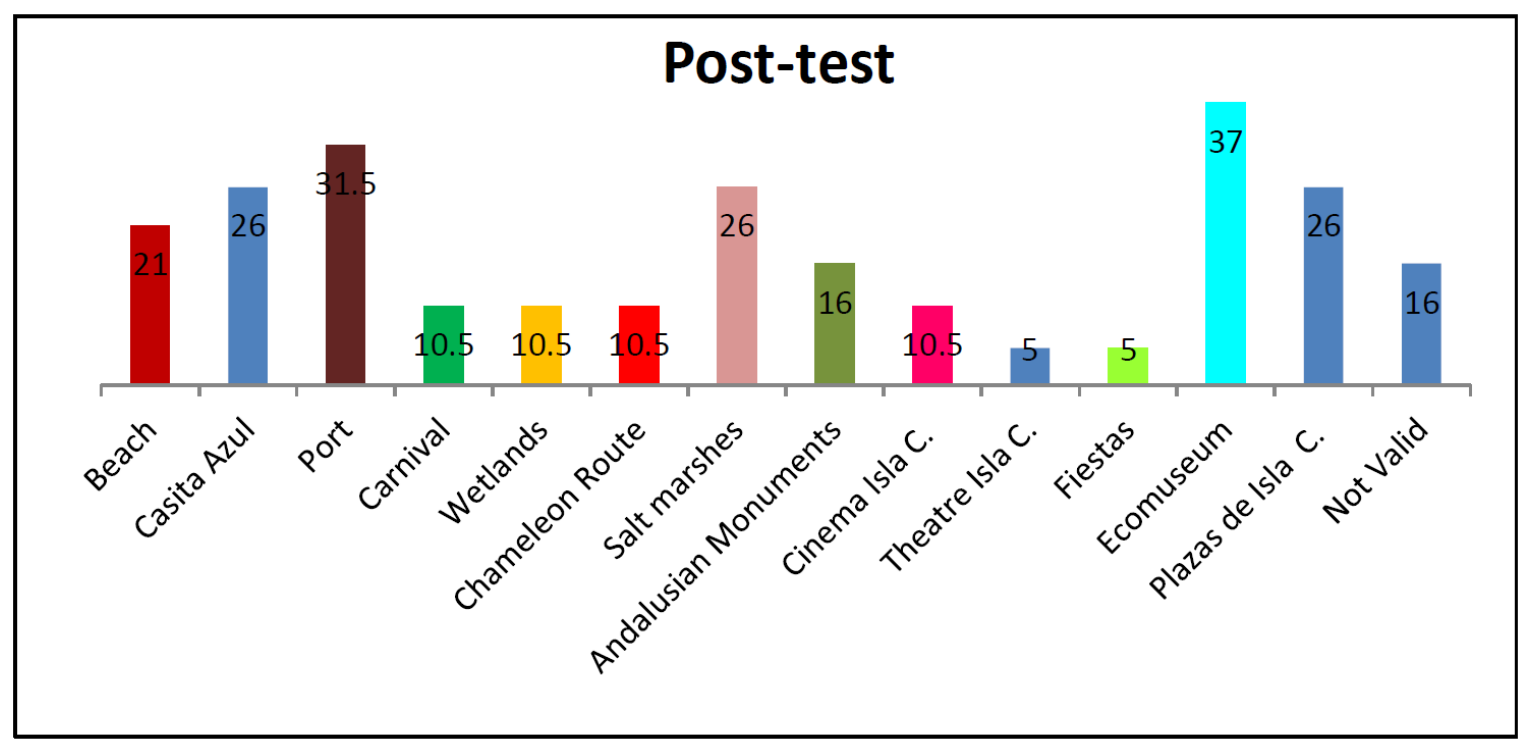

Figure 11. Question 6. Post-test results.

Question 7: From the sections proposed below, please rate with an $\mathrm{X}$ which is most attractive (Table 12 and Figure 12).

The following question concerns those activities rated most attractive to the students. The aim of the question is to investigate which activities are most attractive to the pupils before and after the intervention and to determine whether a didactic proposal that has as its fundamental base the link between school and museum achieves the satisfaction in the students that we consider desirable. To this end, the aim is for pupils to understand school outings or didactic itineraries not as a complementary activity to the unit, but rather as a main activity of the information-seeking phase around which the entire proposal is articulated.

We observed that after the intervention, the attraction of visits to museums, group activities, and visits to the natural park is highlighted to a greater extent. These elements are considered essential for the realization of teaching units that revolve around heritage education. 
Table 12. Results of analysis on the degree of concept evolution. (I Basic level/II Intermediate level/III Desirable level).

\begin{tabular}{|c|c|c|c|c|c|c|}
\hline Time & Degree o & ncept Evolution & Frequency & Percentage & $\begin{array}{c}\text { Valid } \\
\text { Percentage }\end{array}$ & $\begin{array}{c}\text { Accumulated } \\
\text { Percentage }\end{array}$ \\
\hline \multirow{4}{*}{ Pre-test } & \multirow{4}{*}{ Valid } & Basic & 4 & 21.1 & 21.1 & 21.1 \\
\hline & & Intermediate & 12 & 63.2 & 63.2 & 84.2 \\
\hline & & Desirable & 3 & 15.8 & 15.8 & 100.0 \\
\hline & & Total & 19 & 100.0 & 100.0 & \\
\hline \multirow{3}{*}{ Post-test } & \multirow{3}{*}{ Valid } & Intermediate & 10 & 52.6 & 52.6 & 52.6 \\
\hline & & Desirable & 9 & 47.4 & 47.4 & 100.0 \\
\hline & & Total & 19 & 100.0 & 100.0 & \\
\hline
\end{tabular}

We observed that when proposing methodological approaches that include cooperative and collaborative work and encompass activities that require the active participation of students, there is an increase in their interest in activities that involve the museum as a learning space.

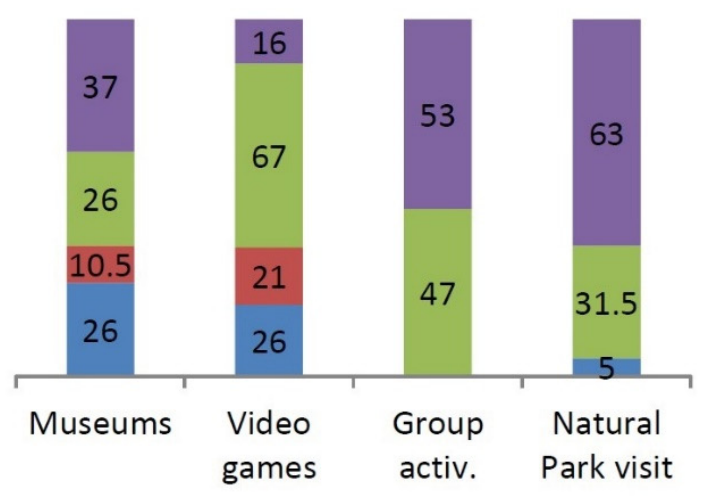

A lot $\square$ Quite $\square$ Not at all $\square$ A little

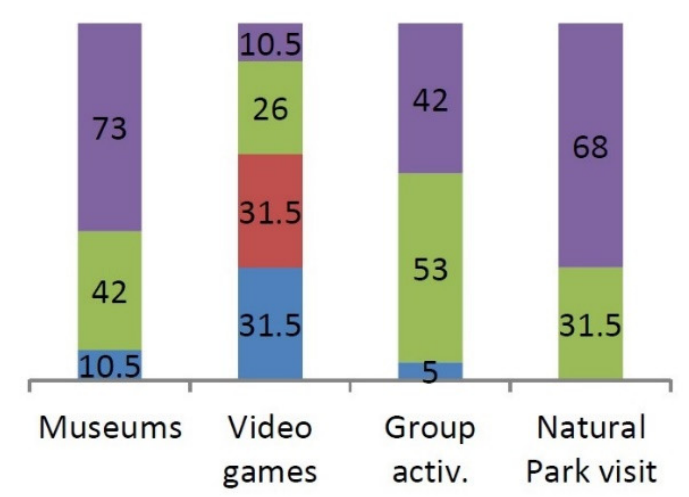

A lot Quite $\quad$ Not at all $\quad$ A little

Figure 12. Question 7. Pre-test and post-test results.

\section{Discussion of Results}

The outcomes achieved in this study allow us to make a general assessment of the relations between schools and heritage institutions, the main object of this work and the HETEIC project within which it is framed. Comparative analysis of the concepts presented here simply highlights how allowing students direct contact with heritage through museums, and the development of didactic proposals of a dynamic, participatory, and socio-critical nature within analysis of the territory fosters the development of much more complex learning than what can be achieved through a more traditional education [35], in which the didactic model is based on one-way transmission methods (teacher to pupil) and the activities proposed are based exclusively on the textbook as curricular material. On the other hand, when making a proposal for problems to be solved by students, it is considered that it breaks with the student passivity characteristic of more traditional teaching models.

Furthermore, from this perspective of territorial analysis and within the framework of the present research, the study by Jiménez de Madariaga and García del Hoyo [36] highlights the need to identify the fishing heritage of the locality in order to protect it. They even considered the possibility of granting fishing an added value through tourism, which, in the case of Isla Cristina, is the second most important economic activity. In their research they offer the possibilities of designing itineraries and tourist activities focused on acknowledgement of this heritage. The results of our work are 
presented along similar lines, although considered from a broader perspective regarding the concept of territorial intelligence.

In the category of heritage conceptualization, both in terms of determining its perspective and typology, a rather significant evolution in the students' thinking is appreciated, mainly due to the development of strategies in which heritage is connected with the social reality of the territory in which the study is framed. This allows the students to understand heritage from a more complex standpoint closer to their interests and experiences. A similar situation is observed in other studies, such as those by Karadeniz [37] or Ott \& Pozzi [38], in which formal education experiences are linked with others of non-formal or informal education, which also affect the students' training.

From another angle, although complementary to the vision described, studies on the evolution of conceptions in teachers and heritage managers show the relevance they give to educational proposals that include work based on interests, expectations, and socio-environmental issues that are relevant to students and the public at large, to encourage that is more motivating, reflective, and persistent over time [11].

The same conceptual evolution is perceived in the case of the citizenship category. The connections between heritage and citizenship allow students to develop a new perspective on the meaning of education in the social sciences, providing a clear social value, which in traditional models is lost. The concept of citizenship and citizen participation evolves towards much more complex levels in the student body as long as their practical meaning is perceived for their development in everyday life, something which can be worked upon through examples based on heritage education [21]. Other examples of positive experiences in this regard are presented in the works of Dusi, Steinbach, and Messeti [39] Geboers, Geijsel, Admiraal, and Dam [40] or Navarro and de Alba [41].

Regarding the territorial intelligence category, some ideas have already been cited in previous paragraphs, given their transversal nature within this study. Analysis of the territory acquires meaning through understanding of the heritage that gives it social identity [42]. This way, as we work with heritage, from contextualizing, participatory, and interactive perspectives, we facilitate the approach to a complex notion of territory by the students, as can be seen in the evolution of their conceptions presented in the previous section.

As shown, the evolution of the students' notions of the heritage-territory-citizenship triangle is enhanced through the relations between two of the most powerful institutions in the educational field, school and museum, in a symbiotic relationship that is key to achieving the basic objectives of education. They are institutions that can complement each other in order to address the social and relevant issues of today from a complex and meaningful perspective, in an analysis that sets out from the present to acquire its meaning in the past, in order to achieve future projections $[43,44]$.

\section{Conclusions and Limitations}

After analyzing the data, we found that the success of the proposal lies, on the one hand, in the integration of conceptual, procedural, and attitudinal contents. The collaborative and cooperative working methodology enabled students to take the reins of their own learning experience, which promoted meaningful learning. Moreover, by working from an integrated vision of heritage, the contents were accommodated within a holistic heritage perspective, encompassing nature, history, culture, and tradition. Due to this, as observed after the post-test analysis, the students were able to assume heritage as a symbolic element of identity, attending to it in all its variants.

Furthermore, the museum's inclusion as an essential element in the sessions encouraged the students' connection with their environment. Museums are thus assumed as spaces for socialization of heritage, given their proximity as familiar elements housing aspects of the daily life of the students, their culture, context, and traditions. It is true that the museum must be configured as an example of good practices regarding its didactic programming. So, after analyzing the case in point and complying with those parameters considered desirable, the inclusion of the El Pintado Tidal Mill Eco-Museum in the classroom schedule enriches the proposal, incorporating natural, landscape, 
cultural, environmental, territorial, and technological elements, among others, while providing the chance to research the use humans make of the different heritage spaces (museum and landscape). It is crucial to offer the students an integral view of the context, studying all elements influencing its construction. In this way, we can understand its evolution, its changes, the human impact on its transformation and encourage reflection on the need for sustainable development. If the pupils understand what they see, they appreciate it, enjoy it, and value its conservation and use.

These statements are reflected in the post-test results, in such a way that after the intervention we found responses from the pupils highlighting the need for sustainable territorial development. For example, in the case of local urban development to the detriment of the environment, the environmental impact was not taken into account in the pre-test phase, whereas in post-test the majority of pupils rejected any kind of aggressive and environmentally unfriendly construction, proposing alternative development measures. This highlights the success of the proposal regarding the training of global citizens who are critical, committed, and participatory with their environment.

Finally, we turn to the Live and Feel Heritage initiative, promoted by the Junta de Andalucía, which lays the foundations for the realization of these proposals. To this end, it provides a raft of resources, dynamics, training sessions, and conceptual and methodological orientations that favor the integration of heritage education in the academic curriculum.

We must point out that the present proposal may be replicable in other contexts, but, to guarantee its success, the background of the participants in it must be properly studied as, in the current case, both the school and the museum institution, as well as the teacher involved, had a background related to good educational practices in heritage education.

Setting out from the research outcomes, we consider the need to include heritage education in the didactic schedule of schools as a measure to encourage citizen education committed to sustainable social, cultural, economic, and natural development of their territories.

Regarding the limitations of the proposed approach, we must emphasize that the teaching context is characterized as difficult to work with. The school comes under the Compensatory Education Plan of the Andalusian Government, designed to support the socio-educational insertion of students with educational needs associated with disadvantaged social and cultural situations. The pupils are characterized by their diversity, both academically and socioculturally, which, together with the great lack of motivation, makes the teaching and learning process difficult. Another of the limitations found was the scarcity of technological resources available in the school, which hindered the search for resources to solve the problem. On the other hand, it should be noted that, after analyzing the information, it was concluded that greater weight should have been given to questions related to group work, camaraderie, interpersonal relationships, and student motivation regarding the design of the activities that took place.

Author Contributions: Conceptualization, M.T.-R. and J.M.C.L.; methodology, M.T.-R.; validation, M.T.-R.; formal analysis, M.T.-R.; investigation, M.T.-R.; resources, M.T.-R. and J.M.C.-L.; data curation, M.T.-R.; writing — original draft preparation, M.T.-R.; writing — review and editing, J.M.C.-L.; visualization, M.T.-R. and J.M.C.-L.; supervision, J.M.C.-L.; funding acquisition, J.M.C.-L. All authors have read and agreed to the published version of the manuscript.

Funding: This work is part of the research project "Heritage Education for the Territorial and Emotional Intelligence of Citizens" (HETEIC), financed by the Ministry of Science, Innovation and Universities and by EU FEDER funding: EDU2015-67953-P.

Acknowledgments: Translated by Neil MacOwan Language Services.

Conflicts of Interest: The authors declare no conflicts of interest. The funders had no role in the design of the study; in the collection, analyses, or interpretation of data; in the writing of the manuscript, or in the decision to publish the results. 


\section{References}

1. Delgado, E.J.; Estepa, J. Educación ciudadana y dimensiones de la memoria en la enseñanza de las ciencias sociales: Investigación sobre las concepciones del profesorado de educación secundaria de Huelva y provincia. Educ. Rev. Fac. Educ. 2017, 20, 259-278. [CrossRef]

2. Lucas, L.; Delgado, E. Educación para una ciudadanía comprometida en la enseñanza de las Ciencias Sociales: Qué piensa el alumnado de un profesor innovador sobre su aprendizaje? Didáctica Cienc. Exp. Soc. 2018, 35, 3-16. [CrossRef]

3. Barghi, R.; Zakaria, Z.; Hamzah, A.; Hashim, N.H. Heritage Education in the Primary School Standard Curriculum of Malaysia. Teach. Teach. Educ. 2017, 61, 124-131. [CrossRef]

4. Estepa, J.; Ávila, R.M.; Ferreras, L. Primary and secondary teachers' conceptions about heritage and heritage education: A comparative analysis. Teach. Teach. Educ. 2018, 24, 2095-2107. [CrossRef]

5. López-Arroyo, C. El Patrimonio en el Contexto Escolar. Análisis de Concepciones Como Vehículo Para el Desarrollo Profesional Docente. Experiencia Didáctica, Farmington Junior High y su Entorno Patrimonial. Ph.D. Thesis, Universidad de Huelva, Huelva, Spain, 2017. Available online: http://rabida.uhu.es/dspace/ handle/10272/1550 (accessed on 9 April 2020).

6. Simşek, G.; Kesici, A.E. Heritage Education for Primary School Children through Drama: The Case of Aydın, Turkey. Procedia-Soc. Behav. Sci. 2012, 46, 3817-3824. [CrossRef]

7. Gómez, C.J.; Miralles, P.; Fontal, O.; Ibáñez, A. Cultural Heritage and Methodological Approaches-An Analysis through Initial Training of History Teachers (Spain-England). Sustainability 2020, 12, 933. [CrossRef]

8. Girardot, J.-J. Coordination Action of the European Network of Territorial Intelligence Final scientific Report. (European Commission, 6th Rtd Framework Programm). 2009. Available online: http://www. territorialintelligence.eu/index.php/caenti/deliverable08 (accessed on 9 April 2020).

9. Miedes, B.; López-Sánchez, C.; Moreno, A. Escenarios alternativos para las tics y el conocimiento territorial en el marco de las transiciones socioecológicas: Smart cities e inteligencia territorial ¿hacia una sociedad del "buen conocer"? In Actas del $2^{\circ}$ Congreso Internacional de Estudios del Desarrollo; Hidalgo, J.L., Moreno-Moreno, A., Eds.; Red Española de Estudios del Desarrollo; Universidad de Huelva: Huelva, Spain, 2014. Available online: https://www.uhu.es/IICIED/actas.php (accessed on 9 April 2020).

10. Rite, M.T.; López, J.M.C. La educación patrimonial para la adquisición de competencias emocionales y territoriales del alumnado de secundaria. Pulso 2017, 40, 159-174.

11. Jiménez, R.; Cuenca, J.M.; Ferreras, M. Heritage education: Exploring the conceptions of teachers and administrators from the perspective of experimental and social science teaching. Teach. Teach. Educ. 2010, 26, 1319-1331. [CrossRef]

12. Girardot, J.-J. Inteligencia territorial y transición socio-ecológica. Rev. Asoc. Estatal Cent. Univ. Relac. Labor. Cienc. Trab. 2010, 23, 11-24.

13. Goren, H.; Yemini, M. Global citizenship education redefined-A systematic review of empirical studies on global citizenship education. Int. J. Educ. Res. 2017, 82, 170-183. [CrossRef]

14. Girardot, J.; Brunau, E. Inteligencia territorial e innovación para el desarrollo socio-ecológica transición. In Proceedings of the 9th International Conference of Territorial Intelligence, ENTI-International Network of Territorial Intelligence, Strasbourg, France, 17-19 November 2010; p. 6.

15. Rodríguez, F. La construcción de identidades en la sociedad actual: Un desafío para la educación y para la democracia. Rev. Española Pedagog. 2008, 66, 85-101.

16. Delgado, E.; Cuenca, J.M. Challenges for the Construction of Identities with Historical Consciousness: Heritage Education and Citizenship Education. In Handbook of Research on Citizenship and Heritage Education; Delgado, E., Cuenca, J.M., Eds.; IGI Global: Hershey, PA, USA, 2020; pp. 1-25.

17. Travé, G.; Molina, J.A.; Delval, J. Enseñar y Aprender Economía en Educación Secundaria; Síntesis: Madrid, Spain, 2018.

18. Cuenca, J.M.; Estepa, J.; Martín-Cáceres, M.J. Patrimonio, educación, identidad y ciudadanía. Profesorado y libros de texto en la enseñanza obligatoria. Rev. Educ. 2017, 375, 136-159. [CrossRef] 
19. Estepa, J.; Martín-Cáceres, M.J. Competencia en conciencia y expresiones culturales y educación histórica: Patrimonios en conflicto y pensamiento crítico. In La Educación Histórica Ante el Reto de las Competencias: Métodos, Recursos y Enfoques de Enseñanza; Miralles, P., Gómez-Carrasco, C.J., Eds.; Octaedro: Barcelona, Spain, 2018; pp. 75-85.

20. Hooper-Grenhill, E. Museums and Their Visitors; Routledge: London, UK, 2013.

21. Cuenca, J.M.; Martín-Cáceres, M.J.; Schugurensky, D. Educación para la ciudadanía e identidad en los museos de Estados Unidos: Análisis desde la perspectiva de la educación patrimonial. Estud. Pedagógicos 2017, 43, 29-48. [CrossRef]

22. Cuenca, J.M.; Molina-Puche, S.; Martín-Cáceres, M. Identity, citizenship and heritage. Comparative analysis of education treatment in museums in the United States of America and Spain. Arbor-Cienc. Pensam. Cult. 2018, 194. [CrossRef]

23. Arbués, E.; Nava, C. Los museos como espacios sociales de educación. Estud. Sobre Educ. 2014, $27,133-151$. [CrossRef]

24. Cuenca, J.M.; López-Cruz, I. Teaching Heritage in Social Sciences, Geography and History Textbooks in Compulsory Secondary Education. Cult. Educ. 2014, 26, 19-37. [CrossRef]

25. Porlán, R.; Martín del Pozo, R. The conceptions of in-service and prospective primary school teachers about the teaching and learning of science. J. Sci. Teach. Educ. 2004, 15, 39-62. [CrossRef]

26. Cuenca, J.M. Heritage in Social Studies Education: Conceptions and Obstacles to Integrate its in Teaching and Learning Compulsory Education; UMI-ProQuest: Ann Arbor, MI, USA, 2004.

27. Shugurensky, D. Global Citizenship Education and Target 4.7: The Challenging Road towards 2030. Glob. Commons Rev. 2018, 2, 22-28.

28. Estepa, J.; Travé, G. Investigación e innovación en el proyecto investigando nuestro mundo (6-12). El ejemplo de las sociedades actuales e históricas en la formación inicial de maestros. Rev. Electrónica Interuniv. Form. Profr. 2012, 15, 113-124.

29. Ruiz, J.; Domínguez, M.; Ferreras, M. Interpretar el territorio para despejar el futuro La experiencia del Ecomuseo Parque Cultural Miraflores, en Sevilla. Íber: Didáctica Cienc. Soc. Geogr. Hist. 2017, 89, $32-37$.

30. Travé, G.; Pozuelos, F.J. Enseñar economía mediante estrategias de investigación escolar. Estudio de caso sobre las concepciones y prácticas del profesorado. Enseñanza Cienc. Soc. 2008, 7, 109-120.

31. Trabajo, M.; Cuenca, J.M. Buenas prácticas escuela-museo: El caso del ecomuseo Molino Mareal de El Pintado. In Innovación Educativa en la Sociedad Digital; Solá, T., Ed.; Dykinson: Madrid, Spain, 2020; pp. 343-355.

32. Johnson, B.R.; Onwuegbuzie, A.J. Mixed methods research: A research paradigm whose time has come. Educ. Res. 2004, 33, 14-26. [CrossRef]

33. Creswell, J.W. Research Design: Qualitative, Quantitative, and Mixed Methods Approaches, 2nd ed.; Sage: Thousand Oaks, CA, USA, 2003.

34. Bisquerra, R. Metodología de Investigación Educativa, 5rd ed.; La Muralla: Madrid, Spain, 2016.

35. Fontal, O.; García-Ceballos, S.; Arias, B.; Arias, V. Assessing the Quality of Heritage Education Programs: Construction and Calibration of the Q-Edutage Scale. Rev. Psicodidáctica 2019, 24, 31-38. [CrossRef]

36. Jiménez de Madariaga, C.; García Del Hoyo, J.J. Enhancing of the cultural fishing heritage and the development of tourism: A case study in Isla Cristina (Spain). Ocean. Coast. Manag. 2019, 168, 1-11. [CrossRef]

37. Karadeniz, C. Children's museums and necessity for children's museums in Turkey. Procedia-Soc. Behav. Sci. 2010, 2, 600-608. [CrossRef]

38. Ott, M.; Pozzi, F. Towards a new era for Cultural Heritage Education: Discussing the role of ICT. Comput. Hum. Behav. 2011, 27, 1365-1371. [CrossRef]

39. Dusi, P.; Steinbach, M.; Messetti, G. Citizenship Education in Multicultural Society: Teachers' Practices. Procedia-Soc. Behav. Sci. 2012, 69, 1410-1419. [CrossRef]

40. Geboers, E.; Geijsel, F.; Admiraal, W.; Dam, G. Review of the effects of citizenship education. Educ. Res. Rev. 2013, 9, 158-173. [CrossRef]

41. Navarro, E.; de Alba, N. Citizenship Education in the European Curricula. Procedia-Soc. Behav. Sci. 2015, 197, 45-49. [CrossRef]

42. Domínguez-Almansa, A.; López-Facal, R. Patrimonio, entorno y procesos de identificación en la educación primaria. Clío: Hist. Hist. Teach. 2015, 41. Available online: http://clio.rediris.es/n41/articulos/mono/ MonFacal2015.pdf (accessed on 9 April 2020). 
43. Akyol, A.A.; Alpagut, A. Educational Projects for the Children at Anatolian Civilization Museum between the Years 2002-2008. Procedia-Soc. Behav. Sci. 2012, 51, 1087-1096. [CrossRef]

44. Okvuran, A. The relationship between arts education, museum education and drama education in elementary education. Procedia-Soc. Behav. Sci. 2010, 2, 5389-5392. [CrossRef]

(C) 2020 by the authors. Licensee MDPI, Basel, Switzerland. This article is an open access article distributed under the terms and conditions of the Creative Commons Attribution (CC BY) license (http://creativecommons.org/licenses/by/4.0/). 